\title{
Fermentation characteristics and chemical composition of elephant grass silage with ground maize and fermented juice of epiphytic lactic acid bacteria
}

\author{
H.F.C. Bezerra ${ }^{1}$, E.M. Santos ${ }^{1}$, J.S. Oliveira ${ }^{1}$, G.G.P. Carvalho ${ }^{2}$, R.M.A. Pinho ${ }^{3 \#}$, T.C. Silva ${ }^{1}$, \\ G.A. Pereira ${ }^{2}$, M.R. Cassuce $^{4}$ \& A.M. Zanine ${ }^{3}$ \\ ${ }^{1}$ Department of Animal Science, Federal University of Paraíba, PB, 58397-000, Areia, Brazil \\ ${ }^{2}$ Department of Animal Science, State University of Bahia, Salvador, BA, 40210-730, Brazil \\ ${ }^{3}$ Department of Animal Science, Federal University of Maranhão, MA, 65500-000, Maranhão, Brazil \\ ${ }^{4}$ Department of Animal Science, Federal Rural University of Pernambuco, PE, 50670-901, Pernambuco, Brazil
}

(Received 4 May 2018; Accepted 26 March 2019; First published online 15 May 2019)

\author{
Copyright resides with the authors in terms of the Creative Commons Attribution 4.0 South African License. \\ See: http://creativecommons.org/licenses/by/4.0/za \\ Condition of use: The user may copy, distribute, transmit and adapt the work, but must recognize the authors and \\ the South African Journal of Animal Science
}

\begin{abstract}
This study aimed to evaluate the microbial populations, fermentation profile, dry matter recovery and chemical composition of elephant grass silage with ground maize (GM) and the fermented juice of epiphytic lactic acid bacteria (FJLB). A factorial design was used with four levels of GM $(0 \mathrm{~g} / \mathrm{kg}, 50 \mathrm{~g} / \mathrm{kg}, 100 \mathrm{~g} / \mathrm{kg}$ and $200 \mathrm{~g} / \mathrm{kg}$ ), untreated or treated with FJLB, in a completely randomized design with five replicates. A preexperiment was undertaken to determine the optimum level of sucrose to be added to fermented juice for the development of epiphytic microflora. In this pre-experiment, a completely randomized design with three replications was used. The treatments were represented by the levels of sucrose $(0 \mathrm{~g} / \mathrm{kg}, 5 \mathrm{~g} / \mathrm{kg}, 10 \mathrm{~g} / \mathrm{kg}, 20$ $\mathrm{g} / \mathrm{kg}, 40 \mathrm{~g} / \mathrm{kg}, 60 \mathrm{~g} / \mathrm{kg}$ and $80 \mathrm{~g} / \mathrm{kg}$, fresh matter basis). The microbial populations, dry matter recovery, and effluent losses were affected by the interaction between GM and FJLB. Dry matter (DM) and crude protein (CP) contents increased linearly with the inclusion of GM. The addition of GM enhanced the fermentation process via a reduction in losses, and improvements were identified in the nutritional value of elephant grass silages. The use of fermented juice increased dry matter recovery, and its effect was more pronounced when ground maize was added.
\end{abstract}

Keywords: dry matter recovery, lactic acid, microbiology, Pennisetum purpureum

\# Corresponding author: ricardo-zootec@hotmail.com

\section{Introduction}

Despite their lower production costs, tropical grasses possess unfavourable characteristics for silage. These include low dry matter (DM) content, high buffering capacity and low content of soluble carbohydrates in the stages of growth (45 to 60 days) that have high nutritional value. These factors can enhance the occurrence of secondary fermentations, thus affecting the conservation process. Grasses may be preserved as silage provided that they are ensiled at their optimum development stage or alongside the use of suitable additives (Zanine et al. 2010).

Lactic fermentation must predominate in the anaerobic conditions so that forage plants can be conserved as silage. However, several factors may interfere with the quality of fermentation, including microorganisms that lead to secondary fermentation, soluble carbohydrates and DM contents, and compacting density (Ferreira et al., 2013).

Several additives have been studied for their use as moisture absorbents, including coffee husk, wheat bran and citrus pulp, but maize meal represents a good alternative owing to its high energetic value (Andrade et al., 2012) and soluble carbohydrate content. Maize meal can also be used as a substrate for microorganisms and contains a considerable amount of starch (Caniato et al., 2004; Zanine et al., 2018) that is not used by lactic acid bacteria (LAB), thus ensuring that the material remains largely intact until the silo is opened. 
Another means of reducing the growth of undesirable microorganisms and minimizing losses by secondary fermentation is the application of homofermentative $L A B$, such as Lactobacillus plantarum, which produces only lactic acid (Santos et al., 2013). The use of microbial inoculants that have been developed from microorganisms contained in the plant (called epiphytic) has been identified as the optimal fermentative profile and facilitates the superior recovery of the ensiled DM (Pereira et al., 2007).

The inoculation of forage crops with fermented juice is said to ensure the dominance of LAB over the ensiling period. To achieve this target, these microorganisms should possess the ability to compete with other organisms and produce an acid pH condition as rapidly as possible (Nishido \& Uchida, 1999).

This study aimed to evaluate the fermentative and microbiological profiles and chemical composition of elephant grass silage with ground maize (GM) and the fermented juice of epiphytic LAB.

\section{Materials and Methods}

The experiment was conducted on an elephant grass pasture (Pennisetum purpureum Schum cv. Roxo) which was already established at the Dairy Cattle Sector of the Animal Science Department of the Agricultural Science Centre, Federal University of Paraiba (UFPB), in the municipality of Areia, PB, coordinates $06^{\circ} 57^{\prime} 46^{\prime \prime}$ and $35^{\circ} 41^{\prime} 31^{\prime \prime}$ W.Gr., at $623 \mathrm{~m}$ altitude. According to Köppen's classification, the climate is As (hot and humid). According to data from the meteorological station of the Agricultural Science Centre, the average annual rainfall in Areia is $1400 \mathrm{~mm}$, the average annual temperature is $24.5^{\circ} \mathrm{C}$, and the relative humidity of the air is $80 \%$.

A completely randomized factorial design was used with four levels of GM $(0 \mathrm{~g} / \mathrm{kg}, 50 \mathrm{~g} / \mathrm{kg}, 100 \mathrm{~g} / \mathrm{kg}$, and $200 \mathrm{~g} / \mathrm{kg}$, fresh matter (FM) basis), without or with fermented juice of epiphytic LAB (FJLB), with five replicates per treatment. The chemical composition of ground maize used is shown in Table 1.

Table 1 Chemical composition of ground maize used as additive in the elephant grass silage

\begin{tabular}{lccccccc}
\hline & DM $^{1}$ & Ash & CP & EE & NDF & ADF & NFC \\
\hline Maize ground (g/kg of DM) & 886.0 & 15.4 & 69.2 & 47.7 & 133.7 & 14.0 & 749.3 \\
\hline
\end{tabular}

DM: g/kg on fresh matter basis; DM: dry matter; CP: crude protein; EE: ether extract; NDF: neutral detergent fibre; ADF: acid detergent fibre; NFC: non-fibre carbohydrates

A pre-experiment was undertaken to determine the optimal level of added sucrose (Olho D'água, União, PI, Brazil) in the fermented juice for the development of epiphytic microflora. In this pre-experiment, a completely randomized design with three replications was used. The treatments were distinguished by levels of sucrose $(0 \mathrm{~g} / \mathrm{kg}, 5 \mathrm{~g} / \mathrm{kg}, 10 \mathrm{~g} / \mathrm{kg}, 20 \mathrm{~g} / \mathrm{kg}, 40 \mathrm{~g} / \mathrm{kg}, 60 \mathrm{~g} / \mathrm{k}$ and $80 \mathrm{~g} / \mathrm{kg} F M$ basis). The grass was harvested at 60 days old and at approximately $2.5 \mathrm{~m}$ height during the vegetative stage, before being chopped in a stationary chopper that had been set to an average particle size of $2.0 \mathrm{~cm}$.

To prepare the juices, $100 \mathrm{~g}$ chopped forage was stowed in a volumetric flask and the volume was completed with one litre of distilled water. The applicable sucrose content was then added to the solution for each treatment. The material was incubated until it reached $\mathrm{pH} 4.0$, with a temperature of approximately $30{ }^{\circ} \mathrm{C}$. The $\mathrm{pH}$ was monitored every four hours. When they reached the expected $\mathrm{pH}$ (16 hours), samples were collected for $L A B$ enumeration. Following $\mathrm{pH}$ monitoring and the counting of $L A B$, the level of $10 \mathrm{~g} / \mathrm{kg}$ was chosen, given that it demonstrated the highest $L A B$ population.

The dose used at the time of inoculation was 1 litre of fermented juice to treat $100 \mathrm{~kg}$ forage, which allowed for the addition of $4.6 \times 10^{7}$ colony-forming units (CFU) of LAB/g FM.

In the experimental phase the grass was harvested at 60 days old and at approximately $2.5 \mathrm{~m}$ in height during vegetative stage, in accordance with the pre-experiment. The number of $L A B$ at harvesting was $6.36 \mathrm{log}$ CFU/g. Shortly after harvesting, the chopped grass was ensiled in silos of polyvinyl chloride with a height of $30 \mathrm{~cm}$ and a diameter of $15 \mathrm{~cm}$, which were equipped with Bunsen's valves to exhaust gases. The amount of $1.5 \mathrm{~kg}$ sand was added to the bottom of the silos to drain the effluent. The compaction of the forage was accomplished via wood sockets with approximately $2 \mathrm{~kg}$ fresh forage per silo. The silos were then sealed, weighed and stored in a covered area at ambient temperature (ranging from $25{ }^{\circ} \mathrm{C}$ to $28{ }^{\circ} \mathrm{C}$ ) until the time of opening.

Before compacting the material in silos, an approximately $300 \mathrm{~g}$ sample of grass was collected to determine DM and water soluble carbohydrates (WSC) at a later date, in line with the AOAC (1990) and Deriaz et al. (1961), respectively. 
Losses and effluents were quantified by weight differences. The losses through gases were obtained via the percentage of DM lost, obtained by the reduction in weight of the DM ensiled. Effluent losses were ascertained from the weight of the effluent that was retained in the sand and expressed as a percentage of FM ensiled. Dry matter recovery (DMR) was estimated by the percentage of DM remaining in the silo at opening in comparison with initial (Ferreira et al., 2016).

The silos were opened 30 days after ensiling. The top and bottom portions of each silo were discarded, corresponding to approximately $5 \mathrm{~cm}$ each, and the central portion was homogenized for use.

The microbial populations were assessed using culture medium selected for each bacterial group, namely Rogosa agar (Difco), at $39^{\circ} \mathrm{C}$ for 48 hours to count the LAB, Violet Red Bile (Difco), at $30{ }^{\circ} \mathrm{C}$ for 24 hours to count the enterobacteria (ENT), and potato dextrose agar at room temperature for seven days, to count moulds and yeasts ( $M \& Y$ ).

The microbial groups were counted by collecting $10 \mathrm{~g}$ of a compound silage sample from the five silos of each treatment and $90 \mathrm{~mL}$ of phosphate buffer solution was added. The solution was then blended in an industrial blender for one minute to obtain a $10^{-1}$ dilution. Serial dilutions were made to obtain dilutions that ranged from $10^{-1}$ to $10^{-9}$. Plates were counted when figures between $30 \mathrm{CFU} / \mathrm{g}$ and $300 \mathrm{CFU} / \mathrm{g}$ were attained.

Following the opening of the silos, sub-samples of approximately $25 \mathrm{~g}$ were collected to analyse the $\mathrm{pH}$ and $100 \mathrm{~mL}$ of water was added following a two-hour rest period. The $\mathrm{pH}$ was read with a potentiometer (Bolsen et al., 1992).

To determine the organic acids, approximately $25 \mathrm{~g}$ fresh silage was diluted in $250 \mathrm{~mL}$ distilled water and homogenized in an industrial blender for one minute. The resulting water extract was filtered through filter paper and $100 \mathrm{~mL}$ was acidified with $50 \%$ of sulphuric acid $\left(\mathrm{H}_{2} \mathrm{SO}_{4}\right)$ before being filtered through fast filter paper (Kung Jr. \& Ranjit, 2001). Then $1 \mathrm{~mL} 20 \%$ metaphosphoric acid solution and $0.2 \mathrm{~mL} 1 \%$ phenic acid solution, used as an internal standard, were added to $2 \mathrm{~mL}$ of this filtrate. Lactic acid (LA), acetic acid (AA) and butyric acid (BA) were determined in a high-performance liquid chromatographer with $210 \mathrm{~nm}$ wavelength. A reverse phase C-18 column was used, with $168 \mathrm{kgf}$ pressure and $1.5 \mathrm{~mL} /$ minute flow.

To assess the chemical composition, FM samples were analysed, first for DM through drying at $105{ }^{\circ} \mathrm{C}$ for 12 hours in a forced air oven, and second for ash and nitrogen content (methods 942.04 and 976.05, respectively, of the AOAC, 1990). The samples were also analysed for neutral detergent fibre (NDF). Heat stable amylase and sodium sulphite were used in the NDF. The contents of DM, organic matter (OM), CP and NDF were determined according to Van Soest et al. (1991).

The content of non-fibrous carbohydrates (NFC) was ascertained using the formula NFC $=100-(\%$ $\mathrm{CP}+\% \mathrm{EE}+\% \mathrm{MM}+\% \mathrm{NDF}$ ) (Mertens, 997). Microbiological and chemical analyses were performed at the Laboratory of Microbiology of Silages and at the Laboratory of Food Analysis and Evaluation, respectively, of the Agricultural Science Centre of UFPB.

Four levels of GM were combined without or with FJLB in a $4 \times 2$ factorial design. Each combination of GM (4) and FJLB (2) was repeated five times and these 40 observations were subjected to an analysis of variance using the model:

$$
Y_{i j k}=a G M_{i}+F J L B_{j}+G M \times F J L B_{i j}+e_{i j k}
$$

where: $Y_{\mathrm{ijk}}$ : trait observed in each replicate of GM level FJLB and fermented juice $\mathrm{j}$

a: overall average, $\mathrm{GM}_{\mathrm{i}}$ : effect of ground maize

FJLB;: effect of fermented juice

$\mathrm{GM}_{\mathrm{i}} \times \mathrm{FJLB}_{\mathrm{j}}$ : interaction between ground maize and fermented juice

$\mathrm{e}_{\mathrm{ij}}$ : random error from each observation

The effects of the fermented juice at the various GM levels were tested using Tukey's test with a probability level of $5 \%$. The effects of GM were evaluated by regression analysis using the determination coefficients and significance of regression parameters as model choice criteria. These parameters were tested using the $t$-test at a probability level of $5 \%$, using the GLM procedure of SAS.

\section{Results}

After 16 hours, the $\mathrm{pH}$ values of the fermented juices of plants were similar, regardless of their levels of sucrose, with an average of 4.06 (Table 2). 
Table 2 Mean values of $\mathrm{pH}$ at various hours of fermentation in fermented juice of elephant grass silage with different levels of sucrose

\begin{tabular}{lccccc}
\hline $\begin{array}{l}\text { Sucrose } \\
\mathbf{( g / k g )}\end{array}$ & $\mathbf{0}$ & $\mathbf{4}$ & $\mathbf{8}$ & $\mathbf{1 2}$ & $\mathbf{1 6}$ \\
\cline { 2 - 6 } & $\mathbf{0}$ & 5.93 & 4.90 & 4.23 & 4.07 \\
\hline 0 & 6.00 & 5.90 & 4.90 & 4.23 & 4.10 \\
5 & 6.00 & 5.70 & 4.77 & 4.17 & 4.07 \\
10 & 5.93 & 5.97 & 4.97 & 4.27 & 4.05 \\
20 & 6.13 & 5.70 & 4.80 & 4.13 & 4.05 \\
40 & 6.17 & 5.60 & 4.90 & 4.27 & 4.05 \\
60 & 5.97 & 5.40 & 4.57 & 4.13 & 4.05 \\
80 & 5.97 & & & & \\
\hline
\end{tabular}

Figure 1 shows the values of $L A B$ populations of the fermented juice of elephant grass according to sucrose levels following 16 hours of rest. An increase in the level of $10 \mathrm{~g} / \mathrm{kg}$ in the LAB populations was observed, with a reduction identified afterwards. Given that the LAB populations were highest, this level was chosen to be used in the ensiling process.

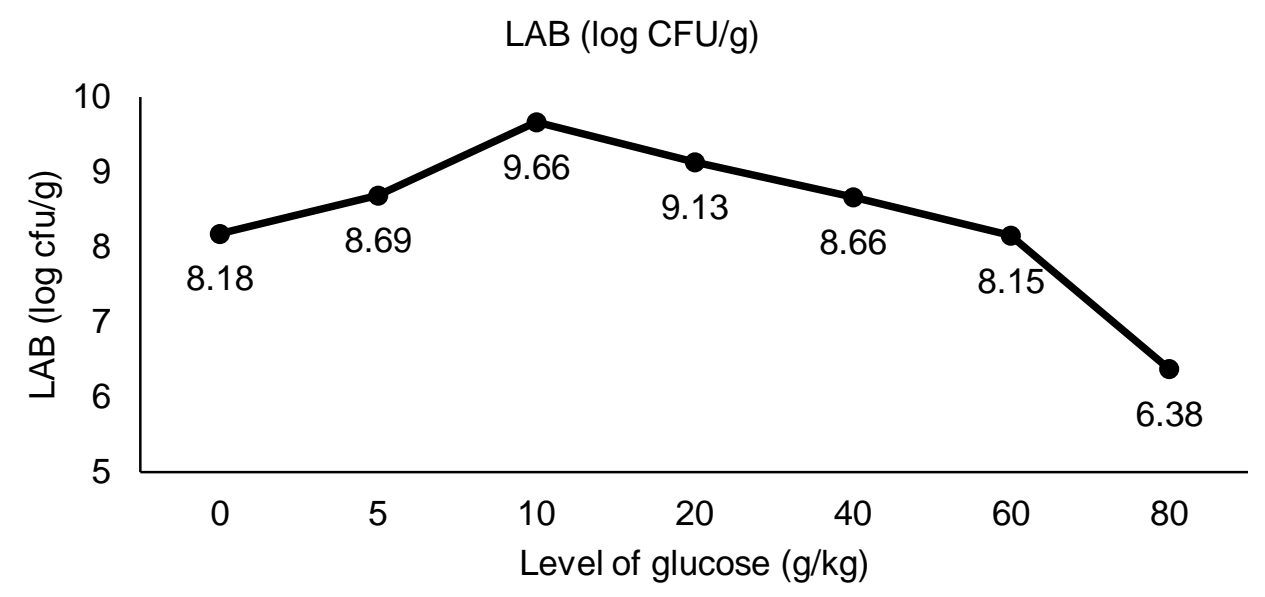

Figure 1 Enumeration of lactic acid bacteria in elephant grass fermented juice with various levels of glucose after 16 hours of incubation

The chemical composition of elephant grass with various GM levels and fermented juice prior to ensiling is displayed in Table 3. All variables increased their contents with the addition of GM, with the exception of the content of NDF.

The microbial populations ( $L A B, E N T$ and $M \& Y$ ) were affected by the interaction between $G M$ and fermented juice $(P<0.01)$ (Table 4$)$. The number of $L A B$ decreased linearly with an increase in the level of GM in the silages that were not treated with FJLB. When the silages were treated with FJLB, the number of LAB increased to 9.2 and $9.18 \mathrm{log} C F U / \mathrm{g}$ (for the levels of GM of $50 \mathrm{~g} / \mathrm{kg}$ and $100 \mathrm{~g} / \mathrm{kg}$ ) and decreased to $8.54 \log \mathrm{CFU} / \mathrm{g}$ in the highest level of $\mathrm{GM}$, demonstrating a quadratic effect $(P<0.01)$. The number of LAB was lowest $(P<0.01)$ in the level of $0 \mathrm{~g} / \mathrm{kg}$ of $\mathrm{GM}$ for silages that were not treated with FJLB. However, in the highest level of $\mathrm{GM}$, the opposite effect was observed $(P<0.01)$.

The inclusion of FJLB stimulated a reduction in the enterobacteria population $(P<0.01)$. Furthermore, this microbial group was not detected in silage with $200 \mathrm{~g} / \mathrm{kg} \mathrm{GM}$ associated with the fermented juice. Rather, in all levels of GM with fermented juice, the silages presented a lower enterobacteria population.

The numbers of $M$ \& $Y$ were higher in the levels of 50 and $200 \mathrm{~g} / \mathrm{kg}$ for silages that were not treated with FJLB as opposed to the FJLB treated silages $(P<0.01)$. However, for silages treated with FJLB, the levels of 0 and 100 of $\mathrm{GM}$ showed the greatest $(P<0.01)$ number of this microbial group. 
Table 3 Chemical composition of elephant grass with various levels of ground maize and fermented juice of epiphytic lactic acid bacteria before ensiling

\begin{tabular}{|c|c|c|c|c|c|}
\hline \multirow{2}{*}{ FJLB } & \multicolumn{4}{|c|}{ Levels of ground maize $(\mathrm{g} / \mathrm{kg})$} & \multirow{2}{*}{ SEM } \\
\hline & 0 & 50 & 100 & 200 & \\
\hline & \multicolumn{4}{|c|}{ Dry matter (g/kg FM) } & 12.63 \\
\hline Without & 209.1 & 228.9 & 249.3 & 320.1 & \\
\hline \multirow[t]{2}{*}{ With } & 195.0 & 219.7 & 250.9 & 323.6 & \\
\hline & \multicolumn{4}{|c|}{ Organic matter (g/kg DM) } & 4.09 \\
\hline Without & 900.2 & 913.8 & 924.4 & 939.3 & \\
\hline \multirow[t]{2}{*}{ With } & 914.0 & 917.9 & 919.5 & 953.7 & \\
\hline & \multicolumn{4}{|c|}{ Crude protein (g/kg DM) } & 2.48 \\
\hline Without & 69.9 & 72.7 & 71.2 & 70.3 & \\
\hline \multirow[t]{2}{*}{ With } & 64.6 & 72.5 & 72.7 & 67.8 & \\
\hline & \multicolumn{4}{|c|}{ Ether extract (g/kg DM) } & 1.18 \\
\hline Without & 20.8 & 24.1 & 28.3 & 29.6 & \\
\hline \multirow[t]{2}{*}{ With } & 20.2 & 21.6 & 25.9 & 30.7 & \\
\hline & \multicolumn{4}{|c|}{ Neutral detergent fibre (g/kg DM) } & 16.70 \\
\hline Without & 706.4 & 653.0 & 597.3 & 553.4 & \\
\hline \multirow[t]{2}{*}{ With } & 707.4 & 630.7 & 564.5 & 537.7 & \\
\hline & \multicolumn{4}{|c|}{ Non-fibre carbohydrates (g/kg DM) } & 20.25 \\
\hline Without & 84.4 & 1634.0 & 238.9 & 285.5 & \\
\hline \multirow[t]{2}{*}{ With } & 122.2 & 193.1 & 256.4 & 317.5 & \\
\hline & \multicolumn{4}{|c|}{ Water soluble carbohydrates (g/kg DM) } & 7.00 \\
\hline Without & 48.6 & 61.3 & 83.7 & 91.7 & \\
\hline With & 45.2 & 63.3 & 85.9 & 97.4 & \\
\hline
\end{tabular}

FM: fresh matter; DM: dry matter; SEM: standard error of the mean

An interaction between ground maize and fermented juice in terms of LA content was observed $(P=$ 0.02 ) (Table 5). The silages treated with fermented juice showed higher concentrations of LA with 50 and $200 \mathrm{~g} / \mathrm{kg}$ of $\mathrm{GM}$ and were equal $(P=0.04)$ in the levels of 0 and $100 \mathrm{~g} / \mathrm{kg}$ of $\mathrm{GM}$ in comparison with the silage that was not treated with FJLB. Quadratic model adjustment was identified $(P<0.01)$, with the maximum point estimated at $59.3825 \mathrm{~g} / \mathrm{kg}$ LA with the addition of $2.64 \mathrm{~g} \mathrm{GM}$ in silages that were not treated with fermented juice. For silages treated with fermented juice, the maximum point estimated was 62.7746 $\mathrm{g} / \mathrm{kg}$ of LA with the addition of $27.4 \mathrm{~g}$ of GM.

The least square means of acetic acid (AA), butyric acid (BA), lactic acid and total acids (LA/TA) ratio, lactic acid and acetic acid (LA/AA) ratio and $\mathrm{pH}$ are presented in Table 6. Treatment with fermented juice did not affect those parameters. The average concentrations of $\mathrm{AA}, \mathrm{BA}$ and $\mathrm{pH}$ were 17 and 16.6, 0.234 and $0.256,3.92$ and 3.94, for untreated and FJLB-treated silages, respectively. The addition of ground maize affected the concentrations of AA, BA, LA/TA, LA/AA and pH quadratically $(P<0.01)$.

When $200 \mathrm{~g} / \mathrm{kg}$ ground maize was included, marked reductions in $\mathrm{pH}(3.76)$ and $\mathrm{AA}(10 \mathrm{~g} / \mathrm{kg})$ and increases in the ratios of LA/TA and LA/AA ( 0.82 and 4.68 , respectively), were observed. 
Table 4 Enumeration of lactic acid bacteria, enterobacteria and moulds and yeasts in elephant grass silages with various levels of ground maize and fermented juice of epiphytic lactic acid bacteria

\begin{tabular}{|c|c|c|c|c|c|c|c|c|}
\hline \multirow{2}{*}{ FJLB } & \multicolumn{4}{|c|}{ Levels of ground maize $(\mathrm{g} / \mathrm{kg})$} & \multirow{2}{*}{ SEM } & \multirow[b]{2}{*}{ GM } & \multicolumn{2}{|c|}{$P$-value } \\
\hline & 0 & 50 & 100 & 200 & & & FJLB & $\mathrm{GM} \times \mathrm{FJLB}$ \\
\hline & \multicolumn{4}{|c|}{ LAB (log CFU/g) } & 1.459 & $<0.01$ & 0.15 & $<0.01$ \\
\hline Without $^{1}$ & $9.61 a$ & 9.37 & 9.53 & $7.85 b$ & & & & \\
\hline \multirow[t]{2}{*}{ With $^{2}$} & $8.96 \mathrm{~b}$ & 9.20 & 9.18 & $8.54 a$ & & & & \\
\hline & \multicolumn{4}{|c|}{ ENT (log CFU/g) } & 2.853 & $<0.01$ & $<0.01$ & $<0.01$ \\
\hline Without $^{3}$ & $3.13 a$ & $3.75 a$ & $3.00 a$ & 2.50 & & & & \\
\hline \multirow[t]{2}{*}{ With } & $2.97 \mathrm{~b}$ & $2.94 b$ & $2.67 \mathrm{~b}$ & ND & & & & \\
\hline & \multicolumn{4}{|c|}{ M\&Y (log UFC/g) } & 1.053 & $<0.01$ & 0.81 & $<0.01$ \\
\hline Without & $4.81 \mathrm{~b}$ & $5.04 a$ & $4.08 \mathrm{~b}$ & $4.77 a$ & & & & \\
\hline With & $5.08 \mathrm{a}$ & $4.08 \mathrm{~b}$ & $5.14 a$ & $4.42 \mathrm{~b}$ & & & & \\
\hline
\end{tabular}

Means in columns with different letters differ significantly by the $\mathrm{F}$ test at the level of 0.05 significance

ND: not detected; FJLB: fermented juice of epiphytic lactic acid bacteria

$\begin{array}{ll}{ }^{1} \hat{Y}=9.8420-0.0086^{*} X & r^{2}=0.7945 \\ { }^{2} \hat{Y}=8.9621-0.0070^{*} X-0.00005^{*} X^{2} & r^{2}=0.9998 \\ { }^{3} \hat{Y}=3.2679+0.0043^{*} X-0.00004^{*} X^{2} & r^{2}=0.7113\end{array}$

LAB: lactic acid bacteria; ENT: enterobacteria; M\&Y: moulds and yeasts; SEM: standard error of the mean

Table 5 Mean values of percentages of lactic acid ( $/ \mathrm{kg} \mathrm{DM}$ ) in elephant grass silages with various levels of ground maize and fermented juice of epiphytic lactic acid bacteria

\begin{tabular}{|c|c|c|c|c|c|c|c|c|}
\hline \multirow{2}{*}{ FJLB } & \multicolumn{4}{|c|}{ Levels of ground maize $(\mathrm{g} / \mathrm{kg})$} & \multirow{2}{*}{ SEM } & \multicolumn{3}{|c|}{$P$-value } \\
\hline & 0 & 50 & 100 & 200 & & GM & FJLB & GM $\times$ FJLB \\
\hline & \multicolumn{4}{|c|}{ LA (g/kg DM) } & 1.32 & $<0.01$ & 0.04 & 0.02 \\
\hline Without $^{1}$ & 59.0 & $59.4 b$ & 55.1 & $42.1 b$ & & & & \\
\hline With $^{2}$ & 60.1 & $67.0 \mathrm{a}$ & 51.2 & $48.7 a$ & & & & \\
\hline
\end{tabular}

Means in columns with unlike letter differ significantly by the $\mathrm{F}$ test at the level of 0.05 significance

${ }^{1} \hat{Y}=59.2950+0.1310^{*} X-0.0500 X^{2} \quad r^{2}=0.9953$

${ }^{2} \hat{Y}=62.7870-0.5030 * X-0.0120 X^{2} \quad r^{2}=0.5977$

FJLB: fermented juice of epiphytic lactic acid bacteria; LA: lactic acid; GM: ground maize; DM: dry matter;

SEM: standard error of the mean

For DMR, interaction $(P<0.01)$ was identified between GM and FJLB (Table 7). Silages treated with FJLB showed higher DMR than silages that were not treated in the absence of GM, namely $933.1 \mathrm{~g} / \mathrm{kg}$ and $858.1 \mathrm{~g} / \mathrm{kg}$, respectively. The same behaviour was observed in silages with the highest levels of GM, namely 962.7 and 898.2, for silages treated and untreated with FJLB, respectively.

An interaction effect $(P<0.01)$ was observed between ground maize and fermented juice for effluent losses. The mean values did differ between untreated and treated with fermented juice at the level of 50 $\mathrm{g} / \mathrm{kg}$, with superior production of effluent for silages treated with fermented juice. The effluent losses decreased linearly $(P<0.01)$ with the inclusion of ground maize and for untreated silages the effluent losses declined by $0.3141 \mathrm{~g} / \mathrm{kg}$ by each $1 \mathrm{~g} / \mathrm{kg}$ of ground maize added to the silage, following the equation:

$$
\hat{Y}=26.2096-0.3141^{\star} X
$$


Table 6 Mean values of acetic acid, butyric acid, lactic acid and total acids ratio, lactic acid and acetic acid ratio and $\mathrm{pH}$ in elephant grass silages with ground maize levels and fermented juice of epiphytic lactic acid bacteria

\begin{tabular}{|c|c|c|c|c|c|c|c|c|c|c|}
\hline & \multicolumn{2}{|c|}{ FJLB } & \multicolumn{4}{|c|}{$\begin{array}{c}\text { Levels of ground maize } \\
(\mathrm{g} / \mathrm{kg})\end{array}$} & \multirow{2}{*}{ SEM } & \multicolumn{3}{|c|}{$P$-value } \\
\hline & Without & With & 0 & 50 & 100 & 200 & & GM & FJLB & $\begin{array}{l}\text { GM } \times \\
\text { FJLB }\end{array}$ \\
\hline${ }^{1} \mathrm{AA}(\mathrm{g} / \mathrm{kg})$ & 17 & 16.6 & 19.9 & 20.2 & 17.1 & 10 & 0.83 & $<0.01$ & 0.73 & 0.18 \\
\hline${ }^{2} \mathrm{BA}(\mathrm{g} / \mathrm{kg})$ & 0.234 & 0.256 & 0.218 & 0.270 & 0.282 & 0.209 & 0.01 & $<0.01$ & 0.07 & 0.06 \\
\hline${ }^{3} \mathrm{LA} / \mathrm{TA}$ & 0.76 & 0.78 & 0.75 & 0.76 & 0.75 & 0.82 & 0.006 & $<0.01$ & 0.11 & 0.37 \\
\hline${ }^{4} \mathrm{LA} / \mathrm{AA}$ & 3.37 & 3.72 & 3.18 & 3.16 & 3.16 & 4.68 & 0.15 & $<0.01$ & 0.11 & 0.24 \\
\hline${ }^{5} \mathrm{pH}$ & 3.92 & 3.94 & 4.02 & 3.93 & 4.01 & 3.76 & 0.02 & $<0.01$ & 0.68 & 0.17 \\
\hline
\end{tabular}

${ }^{1} \hat{Y}=20.1798-0.0044^{\star} X-0.0254^{\star} X^{2}$

${ }^{2} \hat{Y}=0.2280-0.0130 * X-0.0007 * X^{2}$

${ }^{3} \hat{Y}=0.7519-0.0018^{*} X+0.0002^{*} X^{2}$

${ }^{4} \hat{Y}=3.2235-0.0692 * X+0.0071 X^{2}$

${ }^{5} \hat{Y}=3.9959+0.0043^{\star} X-0.0008^{\star} X^{2}$

$$
\begin{aligned}
r^{2} & =0.9887 \\
r^{2} & =0.9909 \\
r^{2} & =0.9860 \\
r^{2} & =0.9877 \\
r^{2} & =0.8217
\end{aligned}
$$

\begin{tabular}{|c|c|c|c|c|c|c|c|c|}
\hline \multirow{2}{*}{ FJLB } & \multicolumn{4}{|c|}{ Levels of ground maize ( $\mathrm{g} / \mathrm{kg})$} & \multirow{2}{*}{ SEM } & \multicolumn{3}{|c|}{$P$-value } \\
\hline & 0 & 50 & 100 & 200 & & GM & FJLB & $\begin{array}{l}\text { GM } \times \\
\text { FJLB }\end{array}$ \\
\hline & \multicolumn{4}{|c|}{ Dry matter recovery (g/kg DM) } & 8.34 & 0.08 & $<0.01$ & $<0.01$ \\
\hline Without & $858.1 b$ & 930.9 & 897.2 & $898.2 b$ & & & & \\
\hline \multirow[t]{2}{*}{ With } & $933.1 \mathrm{a}$ & 903.4 & 928.0 & $962.7 \mathrm{a}$ & & & & \\
\hline & \multicolumn{4}{|c|}{ Effluent losses ( $\mathrm{g} / \mathrm{kg}$ fresh matter) } & 1.84 & $<0.01$ & $<0.01$ & $<0.01$ \\
\hline Without $^{1}$ & 32.59 & $15.26 \mathrm{~b}$ & 6.37 & 3.64 & & & & \\
\hline With $^{2}$ & 31.68 & $23.38 a$ & 8.47 & 4.93 & & & & \\
\hline
\end{tabular}

AA: acetic acid; BA: butyric acid; LA/TA: lactic acid and total acids ratio; LAAA: lactic acid and acetic acid ratio;

FJLB: fermented juice of epiphytic lactic acid bacteria; GM: ground maize; SEM: standard error of the mean

Table 7 Mean values of dry matter recovery and effluent losses in elephant grass silages with various ground maize levels and fermented juice of epiphytic lactic acid bacteria

Means in columns with different letters differ significantly by the $\mathrm{F}$ test at the level of 0.05 significance

${ }^{1} \hat{Y}=26.2096-0.3141^{*} X \quad r^{2}=0.7691$

${ }^{2} \hat{Y}=29.06-0.1366^{*} X \quad r^{2}=0.8600$

FJLB: fermented juice of epiphytic lactic acid bacteria; GM: ground maize; SEM: standard error of the mean

Gas losses were affected $(P<0.01)$ by ground maize (Table 8$)$. However, no model adjustment occurred. A decrease in absolute values between $0 \mathrm{~g} / \mathrm{kg}$ and $200 \mathrm{~g} / \mathrm{kg}$ levels was observed, dropping from 50.7 to $31.1 \mathrm{~g} / \mathrm{kg}$, respectively.

The contents of DM, OM, CP, ether extract (EE) and NFC increased linearly $(P<0.01)$ with the inclusion of ground maize levels (Table 9). Such findings were expected because ground maize contains higher levels of these constituents. DM increased $0.6727 \mathrm{~g} / \mathrm{kg}$ from each $1 \mathrm{~g} / \mathrm{kg}$ of ground maize added to the silage, following the equation:

$$
\hat{Y}=207.390+0.6727^{*} X
$$

ranging from 208.4 to $330.1 \mathrm{~g} / \mathrm{kg}$ for 0 and $200 \mathrm{~g} / \mathrm{kg}$ level, respectively. The NDF content showed a linear decrease $(P<0.01)$ with the increase in ground maize. 
Table 8 Mean values of gases losses in elephant grass silages with various levels of ground maize and fermented juice of epiphytic lactic acid bacteria

\begin{tabular}{|c|c|c|c|c|c|c|c|c|c|c|}
\hline & \multicolumn{2}{|c|}{ FJLB } & \multicolumn{4}{|c|}{$\begin{array}{l}\text { Levels of ground maize } \\
(\mathrm{g} / \mathrm{kg})\end{array}$} & \multirow{2}{*}{ SEM } & \multicolumn{3}{|c|}{$P$-value } \\
\hline & Without & With & 0 & 50 & 100 & 200 & & GM & FJLB & $\begin{array}{l}\text { GM } \times \\
\text { FJLB }\end{array}$ \\
\hline Gas losses & 39.1 & 36.8 & 50.7 & 33.8 & 36.2 & 31.1 & 2.56 & 0.02 & 0.65 & 0.29 \\
\hline
\end{tabular}

FJLB: fermented juice of epiphytic lactic acid bacteria; GM: ground maize; SEM: standard error of the mean

For OM, besides the effect when ground maize was added, a significant effect $(P<0.01)$ was observed with the inclusion of fermented juice, with higher mean values for treated silages $(922.3 \mathrm{~g} / \mathrm{kg})$.

Table 9 Chemical composition of elephant grass silages with various ground maize levels and fermented juice of epiphytic lactic acid bacteria

\begin{tabular}{|c|c|c|c|c|c|c|c|c|c|c|}
\hline & \multicolumn{2}{|c|}{ FJLB } & \multicolumn{4}{|c|}{ Levels of ground maize $(\mathrm{g} / \mathrm{kg})$} & \multirow{2}{*}{ SEM } & \multicolumn{3}{|c|}{$P$-value } \\
\hline & Without & With & 0 & 50 & 100 & 200 & & GM & FJLB & GM $\times$ FJLB \\
\hline $\mathrm{DM}^{1}$ & 253.6 & 255.7 & 208.4 & 228.6 & 251.5 & 330.1 & 2.74 & $<0.01$ & 0.60 & 0.23 \\
\hline $\mathrm{OM}^{2}$ & 915.6 & 922.3 & 901.3 & 908.6 & 925.6 & 940.5 & 1.16 & $<0.01$ & $<0.01$ & 0.14 \\
\hline $\mathrm{CP}^{3}$ & 84.7 & 84.1 & 71.3 & 82.8 & 91.2 & 92.3 & 1.50 & $<0.01$ & 0.83 & 0.42 \\
\hline $\mathrm{EE}^{4}$ & 39.4 & 42.3 & 31.5 & 40.1 & $41.4 \mathrm{~b}$ & 50.6 & 1.44 & $<0.01$ & 0.17 & 0.43 \\
\hline $\mathrm{NDF}^{5}$ & 566.8 & 560.8 & 685.7 & 595.5 & 530.3 & 443.6 & 14.69 & $<0.01$ & 0.24 & 0.31 \\
\hline $\mathrm{NFC}^{6}$ & 225.0 & 241.7 & 138.0 & 219.4 & 292.2 & 382.4 & 14.96 & $<0.01$ & 0.64 & 0.82 \\
\hline
\end{tabular}

Means in rows with different letters differ significantly by the $\mathrm{F}$ test at the level of 0.05 significance

DM: dry matter; OM: organic matter; CP: crude protein; EE: ether extract; NDF: neutral detergent fibre;

NFC: non-fibre carbohydrates; FJLB: fermented juice of epiphytic lactic acid bacteria

${ }^{1} \hat{Y}=207.390+0.6727^{*} X$

${ }^{2} \hat{Y}=901.254+0.2028^{*} X$

${ }^{3} \hat{Y}=48.938+0.0800^{*} X$

${ }^{4} \hat{Y}=33.070+0.0892^{*} X$

${ }^{5} \hat{Y}=667.032-1.4030^{\star} X$

${ }^{6} \hat{Y}=160.502+0.999{ }^{*} X$

$$
\begin{aligned}
& r^{2}=0.9840 \\
& r^{2}=0.9714 \\
& r^{2}=0.7882 \\
& r^{2}=0.9492 \\
& r^{2}=0.9942 \\
& r^{2}=0.9195
\end{aligned}
$$

\section{Discussion}

The intention of adding glucose to the juice was to ensure the growth and domination of the LAB populations, and to facilitate its use as a natural inoculant containing epiphytic microbiota from elephant grass. Glucose is the main substrate that is used by LAB during the fermentation process and it is converted to lactate through the homofermentative pathway (Khalid, 2011). Thus, the decrease observed in $\mathrm{pH}$ as a consequence of LA production by LAB confirmed that these microorganisms can grow and dominate the environment (Table 2). The level of glucose that showed the highest growth of LAB $(10 \mathrm{~g} / \mathrm{kg})$ was chosen to prepare the fermented juice for use in elephant grass ensiling (Figure 1). The reduction in the growth of LAB populations with the addition of higher levels of sucrose (Figure 1) can be associated with the development of other microbial groups, especially yeasts that convert sucrose into alcohol when high concentrations of sucrose are present.

Changes in chemical composition prior to ensiling probably occurred because of the characteristics of ground maize. The WSC content of elephant grass at ensiling increased with the addition of ground maize (Table 3), ranging from $45.2 \mathrm{~g} / \mathrm{kg}$ to $97.4 \mathrm{~g} / \mathrm{kg}$ DM. The increase of WSC levels is related to the inclusion of ground maize, which constitutes an effective additive, increasing the concentration of soluble carbohydrates of the silage, predominantly starch. However, it contains reasonable amounts of other soluble sugars that may be used as a substrate for $L A B$ inside the silo. In evaluating the fermented juice of the epiphytic 
microbiota of guinea grass with the addition of glucose, sucrose and molasses as a substrate for the increase of fermentation, Bureenok et al. (2005a) found $\mathrm{pH}$ values of 4.03 with the addition of $10 \mathrm{~g} / \mathrm{kg}$ sucrose, which are close to the values found in this study at all levels of sugar.

The increase in DM content of elephant grass silage with an additive with high DM content at the time of ensiling was verified by Pinho et al. (2008), who ensiled elephant grass (229 g/ $/ \mathrm{kg} \mathrm{DM}$ ) alongside cassava bran at levels of $0-120 \mathrm{~g} / \mathrm{kg}$, based on FM, and raised to the level of $271 \mathrm{~g} / \mathrm{kg}$. Furthermore, the expected increase with the addition of $200 \mathrm{~g} / \mathrm{kg}$ ground maize instigated DM levels to increase from $195.0 \mathrm{~g} / \mathrm{kg}$ to $323.6 \mathrm{~g} / \mathrm{kg}$, thus within the range recommended to reduce secondary fermentations and hence silage losses in tropical grass silages (Santos et al., 2013).

The number of LAB was lower in silages treated with FJLB in the absence of ground maize, probably because of limited substrates as the WSC in the fresh crop, as demonstrated, with the addition of specific inoculants (Shao et al., 2004). When the WSC were provided with the addition of GM, the number of LAB was higher in the silages treated with FJLB than in the untreated silages. The decline in the numbers of LAB when $200 \mathrm{~g} / \mathrm{kg}$ of GM was probably because of the high amount of WSC provided by the GM, which stimulated the $L A B$ to grow more quickly and reach acid conditions faster than in the other treatments. With accelerated growth, which was caused by a greater amount of initial LAB from the fermented juice, the rapid stabilization of the population - and feasibly a greater decrease of these microorganisms by the superior acidification of the silage - occurred owing to higher levels of LA (Santos et al., 2011). The authors did not observe the high concentration of LA with $200 \mathrm{~g} / \mathrm{kg} \mathrm{GM}$, but the $\mathrm{pH}$ was lowest among the GM levels (Table 6). Bureenok et al. (2005a; 2005b) noted an increase in the LAB populations of $10^{4}$ and $10^{5}$ in the fresh material for values from $10^{8}$ to $10^{9} \mathrm{CFU} / \mathrm{mL}$ in the fermentations of the microbiota of guinea grass with the addition of various sugars. These results demonstrate the effectiveness of added sugars as a substrate for the development of LAB populations when used in appropriate doses.

For ENT, the silages treated with FJLB demonstrated a lower number of such microorganisms than in untreated silages (Table 4), indicating that the use of FJLB is a potential reducer in the development of this microorganism, owing to the rapid acidification of the forage mass. The increasing inclusion levels of GM also reduced the number of ENT. The absence of this microbial group in silages treated with the highest level of GM and FJLB occurred because of the combined effect of the addition of substrate and BAL, which promoted the rapid acidification of the silage mass (Heinritz et al., 2012).

The $M$ \& $Y$ populations were present in all treatments (Table 4). This may be associated with the presence of air inside the silo after closure, and with the soluble carbohydrates of elephant grass. The development of $\mathrm{M} \& \mathrm{Y}$ populations is more closely associated with the presence of oxygen and carbohydrates and is not strongly influenced by the $\mathrm{pH}$ of the silage (Pahlow et al., 2003). This effect might have occurred because the fermentation process was insufficiently intense, unlike in maize silages, which would have allowed for the greater growth of those microorganisms. However, the development of these microorganisms did not compromise the fermentative process, and the loss of DM was not affected.

The reduction of the content of lactic acid and butyric acid in the higher levels of GM may be because of the rapid growth of the $\angle A B$ at the beginning of the fermentation period, and consequently the accentuated drop in $\mathrm{pH}$ that inhibited secondary fermentations once the average values of the content of $A A$ and BA had dropped sharply in the highest level of GM, $10 \mathrm{~g} / \mathrm{kg}$ and $0.209 \mathrm{~g} / \mathrm{kg}$, respectively. This outcome would be confirmed by a decrease in the gas losses and by an increase in the DMR (McDonald, 1991). Furthermore, the use of FJLB in the current study did not affect the production of lactic acid, because the growth of the $L A B$ was not high, probably in terms of a limitation of substrates, as explained for the $L A B$ results.

The values of AA observed in this study indicate that the inclusion of GM at the level of $200 \mathrm{~g} / \mathrm{kg}$ affected WSC markedly, triggering the predominance of lactic acid fermentation. The LA/AA ratio confirms this behaviour. During acetic fermentation, the production of $\mathrm{CO}_{2}$ occurs, which increases DM loss (unlike lactic acid fermentation) (McDonald et al., 1991). When the intensity of this fermentation declines, an increase in DMR is observed, as noted in the current study and in many others that evaluated homofermentative LAB as microbial inoculants (Kung et al., 2003; Santos et al., 2014)

The low content of BA in the present study provides evidence that clostridial activity during the fermentation process is suppressed by the low $\mathrm{pH}$ of all silages.

The addition of FJLB increased DMR probably because of the rapid acidification promoted by the inclusion of LAB. According to Shao et al. (2004) the pre-fermented juice of epiphytic LAB contains more species and numbers of $L A B$, resulting in rapid acidification and $\mathrm{pH}$ reduction. However, it is important to state that evidence of such a pattern (an increase in the number of LAB and concentration of lactic acid) was not observed in the current study.

The increase in DMR with the inclusion of GM may be because of a decline in the moisture content of the ensiled material, reducing secondary fermentation, and resulting in lower losses. In addition, GM provided WSC, which are used as substrates by the LAB and enhance lactic acid fermentation as discussed. 
The absorbent capacity of GM associated with an increase in the DM of the silages justifies the reduction in loss by effluent. Oliveira et al. (2010) observed that the volume of effluent produced in a silo is primarily influenced by the DM content of the forage species ensiled, and that the losses by effluents are minimized when the DM content of silage reaches $300 \mathrm{~g} / \mathrm{kg}$, as shown in Table 1, with the addition of 200 $\mathrm{g} / \mathrm{kg}$ of ground maize. This decrease is important because losses by effluents results in large amounts of nutrients, such as sugars, organic acids and proteins (Loures et al., 2003; Bernardino et al., 2005). Similarly, Andrade et al. (2012) observed a reduction in losses by effluents when ground maize was added to elephant grass silages, causing a loss over $75 \%$ greater than that of silage without the additive.

The reduction of losses by gas with the absorbing additive was also observed by Zanine et al. (2007), who studied elephant grass silages with wheat bran, which is associated with the fact that moistureabsorbing additives inhibit secondary fermentations.

The changes in chemical composition highlight the improvement of the nutritional value of the silage because of the levels of ground maize, thus demonstrating the benefits of using an additive with adequate nutritional value. Associated with the benefits obtained in the fermentation and DM recovery of silage, the use of ground maize may facilitate the use of elephant grass with high nutritional value in the form of silage, thus optimizing the formulation of animal feed with high productive performance.

Because ground maize enables a minimization of losses, this indicates that changes in the medium conditions (and the level of substrate used for fermentation) can direct fermentation in the silo for the production of lactic acid, regardless of the initial population of LAB. This means that, the technique of ensiling elephant grass of considerable high nutritional value presents a new means of feeding highly productive animals.

The use of larger doses of ground maize (such as $200 \mathrm{~g} / \mathrm{kg}$ ) enables superior fermentation in the silo and helps silage to become a positive aspect in feed formulation, especially for high production animals that have greater nutrient requirements.

The fermented juice did not have a marked effect when used without the addition of ground maize, owing to the low content of WSC. Such inoculants may not improve silage quality, given limited substrates in the harvested crop (Bureenok et al., 2005a). However, Ohshima et al. (1997), Tamada et al. (1999), Nishino \& Uchida (1999) and Wang et al. (2009) noted that the addition of fermented juice is effective in increasing the fermentative quality of silage. Further study is needed to clarify the use of fermented juice in improving the fermentative profile and the minimization of losses in tropical grasses.

\section{Conclusions}

The addition of fermented juice does not affect the fermentative profile and chemical composition. The addition of ground maize enhances the fermentation process via a decrease in losses and improves the nutritional value of elephant grass silages. The use of fermented juice increases DM recovery, and its effect is more pronounced when ground maize is added.

\section{Acknowledgements}

The authors also wish to thank the FAPEMA (Maranhão State Research Foundation) for its financial support.

\section{Authors' Contributions}

The research reported was jointly designed, conducted, and interpreted by all the cited authors, who have read and approved the manuscript.

\section{Conflict of Interest Declaration}

None of the authors declare any competing interests.

\section{References}

Association of Official Analytical Methods, 1990. 15th edition. Association of Official Analytical Chemists Inc., Arlington, USA, p.770.

Andrade, A.P., Quadros, D.G., Bezerra, A.R.G., Almeida, J.A.R., Silva, P.H.S. \& Araújo, J.A.M., 2012. Qualitative aspects of elephant grass silage with maize meal and soybean hulls. Semina: Ciênc. Agrárias. 33, 1209-1218. (Eng. Abstr.).

Bernardino, F.S., Garcia, R., Rocha F.C., Souza, A.L. \& Pereira, O.G., 2005. Production and effluent characteristics and bromatological composition of elephant grass silage containing different levels of coffee husk. Braz. J. Anim. Sci. 6, 2185-2191.

Bolsen, K.K., Lin, C., Brent, C.R., Feyerherm, A.M., Urban, J.E. \& Aimutis, W.R., 1992. Effect the silage additives on the microbial succession and fermentation process of alfalfa and maize silages. J. Dairy Sci. 75, 3066-3083.

Bureenok, S., Namihira, T., Kawamoto, Y. \& Nakada, T., 2005a. Additive effects of fermented juice of epiphytic lactic acid bacteria on the fermentative quality of guinea grass (Panicum Maximum Jacq.) silage. Grassl. Sci. 51, 243-248. 
Bureenok, S., Namihira, T., Tamaki, M., Mizumachi, S., Kawamoto, Y. \& Nakada, T., 2005b. Fermentative quality of guineagrass silage by using fermented juice of the epiphytic lactic acid bacteria (FJLB) as a silage additive. Asian-Austral J. Anim. Sci. 18, 807-811.

Bureenok, S., Tamaki, M., Kawamoto, Y. \& Nakada, T., 2007. Additive effects of green tea on fermented juice of epiphytic lactic acid bacteria (FJLB) and the fermentative quality of Rhodes grass silage. Asian-Austral. J. Anim. Sci. 20, 920-924.

Caniato, F.F., Galvão, J.C.C., Finger, F.L., Ribeiro, R.A., Miranda, G.V. \& Puiatti, M., 2004. Study of total soluble sugars, reducing sugars and starch composition in immature kernels of maize cultivars. Braz. J. Maize and Sorghum 3 , 38-44.

Deriaz, R.E., 1961. Routine analysis of carbohydrate and lignin in herbage. J. Sci. Food Agric. 12, 150-160.

Ferreira, D.J., Lana, R.P., Zanine, A.M., Santos, E.M., Veloso, C.M. \& Queiroz, A.C., 2013. Silage fermentation and chemical composition of elephant grass inoculated with rumen strains of Streptococcus bovis. Anim. Feed Sci. Technol. 183, 22-28.

Ferreira, D.J., Zanine, A.M., Lana, R.P., Souza, A.L., Ribeiro, M.D., Negrão, FM., Castro, W.J.R., Parente, H.N., Geron, L.J.V. \& Camara, L.R.A., 2016. Ingestive behavior of ovine fed with Marandu grass silage added with naturally dehydrated brewery residue. Sci. World J. 23, 1-7.

Heinritz, S.N., Martens, S.D., Avila, P. \& Hoedtje, S., 2012. The effect of inoculant and sucrose addition on the silage quality of tropical forage legumes with varying ensilability. Anim. Feed Sci. Technol. 174, 201-210.

Khalid, K., 2001. An overview of lactic acid bacteria. Int. J. Bioscien. 1, 1-13.

Kung Jr., L. \& Ranjit, N.K., 2001. The effect of Lactobacillus buchneri and other additives on the fermentation and aerobic stability of barley silage. J. Dairy Sci. 84, 1149-1155.

Kung, L., Stokes, M.R. \& Lin, C.J., 2003. Silage Additives. In: D.R. Buxton, R.E. Muck \& J.H Harrison (eds.) Silage science and technology. 1st edition. Madison: Am. Soc. Agron. pp. 31-94.

Loures, D.R.S., Garcia, R., Pereira, O.G. Cecon, P.R. \& Souza, A.L., 2003. Effluent characteristics and chemicalbromatologic compound of elephant grass silage under different levels of pressure. Braz. J. Anim. Sci. 6, 851-1858.

McDonald, P., Henderson, A.R. \& Heron, S.J., 1991. The biochemistry of silage. 2nd edition. Chalcombe, Marlow. 340 p.

Mertens, D.R., 1997. Creating a system for meeting the fiber requirements of dairy cows. J. Dairy Sci. 80, $1463-1481$.

Mertens, D.R., 2002. Gravimetric determination of amylase treated neutral detergent fiber in feeds with refluxing in beaker or crucibles: Collaborative study. J. AOAC Intern. 85, 1217-1240.

Nishido, N. \& Uchida, S., 1999. Laboratory evaluation of previously fermented juice as a fermentation stimulant for lucerne silage. J. Sci. Food Agric. 79, 1285-1288.

Ohshima M., Cao, L., Kimura, E., Ohshima, Y. \& Yokota, H., 1997. Influence of addition of previously fermented juice to alfalfa ensiled at different moisture contents. J. Sci. Food Agric. 43, 56-58.

Oliveira, L.B., Pires, A.J.V., Carvalho, G.G.P., Ribeiro, L.S.O., Almeida, V.V. \& Peixoto, C.A.M., 2010. Losses and nutritional value of maize, Sudan sorghum, forage sorghum and sunflower silages. Braz. J. Anim. Sci. 39, 61-67.

Pahlow, G., Muck, R.E., Driehuis, F., Oude Elferink, S.J.W.H. \& Spoelstra, S.F., 2003. Microbiology of ensiling. In: Silage Science and Technology. Edited by Buxton, D.R., Muck, R.E. \& Harrison, J.H. Crop Science Society of America; Soil Science Society of America, Madison. pp. 31-93.

Penteado, D.C.S., Santos, E.M., Carvalho, G.G.G.P., Oliveira, J.S., Zanine, A.M. \& Pereira, O.G., 2007. Lactobacillus plantarum from microbiota as inoculant for Panicum maximum silage. Arch. Zootec. 57, 35-42.

Pereira, O.G., Rocha, K.D. \& Ferreira, C.L.LF., 2007. Chemical composition, characterization, and population of microorganisms on elephant grass Cameroon (Pennisetum purpureum, Schum) and its silages. Braz. J. Anim. Sci. 36, 1742-1750.

Pinho, B.D., Pires, A.J.V., Ribeiro, L.S.O. \& Carvalho, G.G.P., 2008. Ensilage of elephant grass containing cassava meal. J. Anim. Health Prod. 9, 641-645.

Santos, E.M. \& Zanine, A.M., 2006. Grass of silage tropical. Colloq. Agrar. 2, 32-45.

Santos, E.M., Zanine, A.M., Ferreira, D.J., Oliveira, J.S., Penteado, D.C.S. \& Pereira, O.G., 2008. Activated inoculant improve Tanzania grass (Panicum Maximum) silage. Arch. Zoot. 57, 35-42.

Santos, E.M., Pereira, O.G., Garcia, R., Ferreira, C.L.L.F., Oliveira, J.S., Silva, T.C. \& Rosa, L.O., 2011. Microbial populations, fermentative profile and chemical composition of signal grass silages at different regrowth ages. Braz. J. Anim. Sci. 40, 747-755.

Santos, E.M., Silva, T.C., Macedo, C.H.O., Campos, F.S., 2013. Lactic acid bacteria in tropical grass silages, lactic acid bacteria - R \& D for Food, Health and Livestock Purposes. Edited by M. Kongo. In: Tech, Croatia, 335-362.

Santos, E.M., Pereira, O.G., Garcia, R., Ferreira, C.L.L.F., Oliveira, J.S. \& Silva, T.C., 2014. Effect of regrowth interval and a microbial inoculant on the fermentation profile and dry matter recovery of guinea grass silages. J. Dairy Sci. $97,1-10$

Shao, T., Ohba, N., Shimojo, M. \& Masuda, Y., 2004. Effects of adding glucose, sorbic acid and pre-fermented juices on the fermentation quality of Guinea grass (Panicum maximum Jack.) silages. Asian-Austral. J. Anim. Sci. 17, 808-813.

Silva, P.A., Valadares Filho, S.C., Valadares, R.F.D., Cecon, P.R., Detmann, E. \& Paixão, M.L., 2007. Energy value of elephant grass at different regrowth ages and estimate of in vivo neutral detergent fiber digestibility. Braz. Arch. of Vet. Med. and Anim. Sci. 59, 711-718.

Statistical Analysis System, 2001. User's guide: Statistics, Version 8.2. SAS Institute, Cary, NC, USA. 
Tamada, J., Yokota, H., Ohshima, M. \& Tamaki M., 1999. Effect of additives, storage temperature and regional difference of ensiling on the fermentation quality of Napier grass (Penisetum purpureum Schum.) silage. AsianAustral. J. Anim. Sci. 12, 28-35.

Van Soest, P.J., Robertson, J.B. \& Lewis, B.A., 1991. Methods for dietary fiber, neutral detergent fiber, and non-starch polysaccharides in relation to animal nutrition. J. Dairy Sci. 74, 3583-3597.

Wang, J., Wang, J.Q., Zhou, H. \& Feng, T., 2009. Effects of addition of previously fermented juice prepared from alfalfa on fermentation quality and protein degradation of alfalfa silage. J. Feed Sci. Technol. 151, 280-290.

Zanine, A.M., Santos, E.M., Ferreira, D.J. \& Pereira, O.G., 2007. Microbial population and nutritional compounds in the organs of Tanzania grass before and after ensilage. Semina: Ciênc. Agrárias 28, 143-150. (English abstract)

Zanine, A.M., Santos, E.M., Dorea, J.R.R., Dantas, P.A.S., Silva, T.C. \& Pereira, O.G., 2010. Evaluation of elephant grass with addition of cassava scrapings. Braz. J. Anim. Sci. 39, 2611-2616.

Zanine, A.M., Bonelli, E.A., Ferreira, D.J., Santos, E.M., Pinho, R.M.A. \& Parente, H.N., 2018. Fermentation and chemical composition of guinea grass silage added with wheat meal and Streptococcus bovis. New Zealand J. Agri. Res. 3, 1-8. 